\title{
Artikel
}

\section{De immuniteit van de feitelijk leidinggever na NJ 2018/134 (Stichtse Vecht)}

\author{
Een analyse in het licht van de uit artikel 2 EVRM voortvloeiende positieve verplichtingen
}

Mr. dr. M.J. Hornman*

\section{Inleiding}

Hoewel in de literatuur al vrij eensgezind werd aangenomen dat de strafrechtelijke immuniteit van overheidslichamen haar langste tijd had gehad, ${ }^{1}$ besloot de Eerste Kamer op 10 november 2015 met een minieme meerderheid van slechts één stem verschil anders. ${ }^{2}$ Met die voor velen onverwachte uitkomst kiest de wetgever, in weerwil van de daarop veelvuldig geuite kritiek, voor het behoud van de status quo inzake de immuniteit van centrale en decentrale overheidslichamen en hun feitelijk leidinggevers. Dat standpunt is niet alleen in het licht van die kritiek, maar ook gezien de ontwikkelingen elders in Europa, opvallend. Zo hebben onze zuiderburen afgelopen zomer juist besloten om de strafrechtelijke immuniteit van publiekrechtelijke

* Mr. dr. M.J. Hornman is werkzaam bij de afdeling Juridische Zaken van de Autoriteit Financiële Markten. Dit artikel is op persoonlijke titel geschreven.

1. Zie o.a. D.R. Doorenbos, 'Verdedigingsrechten van rechtspersonen in het strafproces', in: S. Lierman e.a. (red.), Vereniging voor de vergelijkende studie van het recht in België en Nederland - Preadviezen 2015, Den Haag: Boom Juridische uitgevers 2015, p. 201 voetnoot 13; A.N. Kesteloo, De rechtspersoon in het strafrecht, Deventer: Kluwer 2013, p. 22-24; R. Rijnhout, E. Sikkema en W.S. de Zanger, 'Strafrechtelijke en civielrechtelijke aansprakelijkheid van de overheid als wegbeheerder bij dodelijke ongevallen; de zaak Stichtse Vecht', Rechtsgeleerd Magaziin THEMIS 2014, p. 14

2. Handelingen I 2015/16, 30538, 7 . rechtspersonen op te heffen ${ }^{3}$ en is ook in andere EU-lidstaten een tendens waarneembaar in de richting van een verruiming van de strafrechtelijke aansprakelijkheid van rechtspersonen.

Over de keuze van de wetgever, het Stichtse Vechtarrest en alle anverwante materie zijn in korte tijd al meerdere lezenswaardige bijdragen verschenen, ook in dit tijdschrift. ${ }^{4}$ Het is niet de bedoeling van dit artikel om de daarin gevoerde discussie nogmaals over te doen. In het navolgende zal, na een uiteenzetting van het geldende immuniteitskader, nader worden ingezoomd op de positie van de feitelijk leidinggever. ${ }^{5}$ De beschrijving daarvan komt er in de literatuur namelijk nogal bekaaid vanaf. Primair omdat diens immuniteit rechtstreeks wordt ontleend aan de immuniteit van het openbare lichaam waaraan deze is verbonden. Daarnaast bestaat er in de literatuur weliswaar discussie over de mate waarin de rechtspraak van het Europees Hof voor de Rechten

3. Http://www.ejustice.just.fgov.be/eli/wet/2018/07/11/2018040329/ justel. Zie hierover nader D. Roef, 'België heeft de strafrechtelijke immuniteit van overheden afgeschaft: een voorbeeld voor Nederland?', Strafblad 2018, p. 44-49 (verder: Roef 2018a).

4. Zie o.a. Rijnhout, Sikkema \& De Zanger 2014, p. 10-25; R.R. Crince le Roy en R.S. Wijling, 'Recht op strafvervolging van de overheid?', Gst. 2018, p. 222-232; A.P.W. Duijkersloot, 'Bestraffing van de overheid: stand van zaken sinds 2010', TvSO 2016, p. 61-66; H.R.B.M. Kummeling en M.J. Vetzo, 'Opheffing strafrechtelijke immuniteiten verworpen door de Eerste Kamer', O\&A 2016, p. 62-63; D. Roef, 'De strafrechtelijke positie van de overheid anno 2018: een stand van de rechtsontwikkeling', O\&A 2018, p. 113-123 (verder: Roef 2018b); E. Sikkema, 'Twee wetsvoorstellen over de strafbare overheid', NJB 2006, p. 1994-2001; E. Sikkema, 'Strafvervolging van een gemeente: een einde aan de spraakverwarring?', TBS\&H 2018, p. 1-3.

5. Waar in het navolgende over de feitelijk leidinggever wordt gesproken, moet daaronder eveneens de opdrachtgever worden begrepen. 
van de Mens (hierna: EHRM) dwingt tot de opheffing van de immuniteit van openbare lichamen, maar wordt vrij eensgezind aangenomen dat de immuniteit van de feitelijk leidinggever onverenigbaar is met de positieve verplichtingen die voortvloeien uit artikel 2 van het Europees Verdrag voor de Rechten van de Mens (hierna: EVRM). ${ }^{6} \mathrm{Bij}$ de juistheid van die opvatting heb ik zo mijn twijfels. Ook meen ik dat het vervolgen van feitelijk leidinggevers in de praktijk niet altijd eenvoudig zal zijn en om meerdere redenen op principiële bezwaren zal stuiten, waardoor de haalbaarheid en opportuniteit van dergelijke vervolgingen kan worden betwijfeld. Anders dan het EHRM lijkt aan te nemen, vormt de persoonlijke aansprakelijkheid van overheidsfunctionarissen geen alternatief voor de aansprakelijkheid van het overheidslichaam zelf.

Deze bijdrage is als volgt opgebouwd. In paragraaf 2 zal het juridische kader zoals dat voortvloeit uit de Pikmeerjurisprudentie worden geschetst om zo inzicht te geven in de reikwijdte van het exclusieve bestuurstaakcriterium. Vervolgens zal in paragraaf 3 en 4 worden ingegaan op de kritiek die is geuit op dit criterium en op de koppeling van de immuniteit van de feitelijk leidinggever aan de immuniteit van het openbare lichaam waaraan hij of zij is verbonden. Aansluitend wordt in paragraaf 5 en 6 nader ingezoomd op de mensenrechtelijke component van die kritiek. Allereerst zal daarbij worden ingegaan op de vermeende inwisselbaarheid van de aansprakelijkheid van de overheid en haar functionarissen. Daarna zal aandacht worden besteed aan de door het Hof geformuleerde voorwaarden waaronder vervolging van openbare lichamen en/of hun functionarissen mogelijk moet zijn. De Straatsburgse positieve verplichtingen-rechtspraak vormt in de literatuur immers het belangrijkste bezwaar tegen de immuniteit, maar op de stelligheid waarmee wordt verkondigd dat de voornoemde koppeling onhoudbaar is, valt mijns inziens het nodige af te dingen. In paragraaf 7 zal ten slotte kort worden ingegaan op de vraag of onderzoek door de Onderzoeksraad voor Veiligheid een alternatief kan vormen voor het instellen van een strafrechtelijk onderzoek. Conclusie van deze bijdrage zal zijn dat er vele goede en overtuigende argumenten zijn om de gedeelde immuniteit van de feitelijk leidinggever op te heffen, maar dat de positieve verplichtingen-rechtspraak niet tot een opheffing daarvan verplicht.

6. Zie o.a. T. Barkhuysen en M.L. van Emmerik, 'EHRM-uitspraak Öneryildiz tegen Turkije: Europese grenzen aan het gedogen van gevaarlijke situaties en aan beperkingen van overheidsaansprakelijkheid bij ongelukken en rampen', O\&A 2003, par. 4.3; T. Barkhuysen en M.L. van Emmerik, 'Overheidsaansprakelijkheid voor falend toezicht en ontoereikende handhaving Nadere lessen uit de uitspraak van de Grote Kamer van het EHRM inzake Öneryildiz tegen Turkije?', O\&A 2005, par. 5.2; Crince le Roy \& Wijling 2018, p. 225-227; Rijnhout, Sikkema \& De Zanger 2014, p. 19; E. van Sliedrecht, 'Immuniteit van de Staat: de houdbaarheid voorbij?' in: Immuniteiten (Preadviezen Nederlandse Juristen Vereniging 2013-I), Deventer: Kluwer 2013, p. 166-167; S.N. de Valk, Aansprakelijkheid van leidinggevenden (diss. Groningen), Deventer: Kluwer 2009, p. 362-365.

\section{Het exclusieve bestuurstaak- criterium na Stichtse Vecht}

Aan de centrale overheid en haar functionarissen komt volledige immuniteit toe. ${ }^{7}$ Ingevolge het Pikmeer IIarrest genieten decentrale openbare lichamen strafrechtelijk enkel immuniteit voor hun handelen voor zover de ten laste gelegde gedragingen naar hun 'aard en gelet op het wettelijk systeem rechtens niet anders dan door bestuursfunctionarissen kunnen worden verricht in het kader van de uitvoering van de aan het openbaar lichaam opgedragen bestuurstaak, zodat uitgesloten is dat derden in zoverre op gelijke voet als het openbaar lichaam aan het maatschappelijk verkeer deelnemen. ${ }^{8}$ De enkele omstandigheid dat een bepaalde taak bij wet aan het openbare lichaam is opgedragen of in het algemeen als overheidstaak wordt gezien is dus niet doorslaggevend. De nadruk ligt immers niet zozeer op de bestuurstaak als zodanig, maar veeleer op het exclusieve karakter van de in het kader van die bestuurstak verrichte gedraging. ${ }^{9}$ Dat de bestuurlijke verantwoordelijkheid bij de overheid blijft liggen neemt niet weg dat de bestuurstaak feitelijk ook door derden kan worden uitgevoerd. ${ }^{10}$ Bepalend is dus niet of de gedraging in het kader van een exclusieve bestuurstaak is verricht, maar of de gedraging zelf 'exclusief' is, in die zin dat zij uitsluitend is voorbehouden aan de overheid en niet anders dan in het kader van een overheidstaak kan worden verricht. ${ }^{11}$ Daarbij kan worden gedacht aan het verstrekken van vergunningen, het toezicht op de naleving van vergunningsvoorschriften, het handhavend optreden tegen overtredingen daarvan of het afzien van handhavend optreden (gedogen). ${ }^{12}$

De meest recente loot aan de stam van deze jurisprudentie wordt gevormd door het Stichtse Vecht-arrest van februari 2018. Hierin waren een motorrijdster en haar bijrijder als gevolg van hobbels in het wegdek ten val gekomen en aangereden door een tegemoetkomende bedrijfsauto, als gevolg waarvan zij zwaar lichamelijk letsel hebben opgelopen waaraan zij uiteindelijk zijn

7. HR 25 januari 1994, ECLI:NL:HR:1994:ZC9616, NJ 1994/598 m.nt. G.J.M. Corstens (Vliegbasis Volkel).

8. HR 6 januari 1998, ECLI:NL:HR:1998:AA9342, NJ 1998/367 m.nt. J. de Hullu (Pikmeer II);

9. D. Roef, 'De immuniteit van overheden: een stand van zaken in EVRMperspectief', Strafblad 2012, p. 186-187; Roef 2018b, p. 113-115.

10. HR 18 september 2007, ECLI:NL:HR:2007:BA6575, NJ 2007/512 (Zederik); Hof Arnhem-Leeuwaren 2 november 2016, ECLI:NL:GHARL: 2016:10631 (Beuningen); Rb. Utrecht 9 juli 2003, ECLI:NL:RBUTR: 2003:AH9535, AB 2003/332 m.nt. J.A.F. Peters (Verdronken brandweerman); Roef 2012, p. 186; Roef 2018b, p. 113-114.

11. Rijnhout, Sikkema \& De Zanger 2014, p. 12; D. Roef, Strafbare Overheden. Een rechtsvergelijkende studie naar de strafrechtelijke aansprakelijkheid van overheden voor milieuverstoring (diss. Maastricht), Antwerpen-Groningen: Intersentia 2001, p. 266; Roef 2018b, p. 117.

12. Hof Arnhem 23 september 2002, ECLI:NL:GHARN:2002:AE7956, NJ 2002/550 (Artikel 12 Sv-procedure Vuurwerkramp Enschede); HR 24 september 2013, ECLI:NL:HR:2013:765, NJ 2014/241 m.nt. J.M. Reijntjes (Probo Koala); Rb. Den Haag 20 februari 2018, ECLI:NL:RBDHA:2018:1658 (Sterigenics). 
overleden. ${ }^{13}$ De gemeente werd daarop vervolgd wegens dood door schuld (art. $307 \mathrm{Sr}$ ), waarbij het schuldverwijt tweeledig was. De gemeente zou hebben nagelaten om passende verkeersmaatregelen te nemen en zij zou hebben nagelaten om het benodigde onderhoud aan de weg te verrichten. Van het tweede nalaten wordt de gemeente door de rechtbank vrijgesproken, mede vanwege het feit dat het causale verband op dit punt lastig is vast te stellen. Ook zou voor een veroordeling op dit punt nader onderzoek nodig zijn naar de vraag of dergelijke onderhoudswerkzaamheden op gelijke voet door derden kunnen worden verricht. De feitelijke uitvoering vormt daarbij niet zozeer het probleem, wel de vraag of die derde ook zelfstandig zou kunnen besluiten om tot het nemen van dergelijke maatregelen over te gaan. ${ }^{14}$ Het eerste nalaten acht de rechtbank wel bewezen, waarbij zij tot de conclusie komt dat van immuniteit geen sprake kan zijn nu de gemeente een (feitelijk) niet-uitvoeren wordt verweten en geen (bestuurlijke) besluitvorming. ${ }^{15}$ Daarmee belicht deze casus meteen het pijnpunt uit het exclusieve bestuurstaak-criterium. Weliswaar kan de feitelijke uitvoering van veel bestuurstaken worden overgelaten aan derden, maar het daaraan voorafgaande besluit kan veelal alleen door een bestuursorgaan worden genomen. Waarin beide omissies op dit punt volgens de rechtbank verschillen, wordt niet direct duidelijk. ${ }^{16}$ Bovendien rust de rechtsplicht om die taken naar behoren te verrichten op de overheid. Het is daarom de vraag of die rechtsplicht zich eveneens uit handen laat geven, zodat derden daadwerkelijk op gelijke voet kunnen optreden. De Stichtse Vecht-casus laat zien dat de rechtbank met die vraag heeft geworsteld. Rijnhout c.s. hebben betoogd dat met het opdragen van het feitelijk onderhoud aan derden ook de rechtsplicht om dat onderhoud te verrichten op die derden overgaat, zodat zij op gelijke voet wegens het nalaten van dat onderhoud kunnen worden aangesproken. ${ }^{17}$ Advocaat-Generaal (hierna: A-G) Machielse ziet dat duidelijk anders en meent dat de rechtsplicht ook in dat geval ingevolge het wettelijke systeem van de Wegenwet bij de gemeente blijft rusten. Ook het oordeel dat het nemen van maatregelen buiten de exclusieve bestuurstaak valt, vindt in zijn ogen geen genade. Het plaatsen van (rechtsgeldige) ge- of verbodsborden vergt een gemeentelijk verkeersbesluit. Dat is een exclusieve bestuurstaak. ${ }^{18}$ De Hoge Raad gaat deels met zijn A-G mee. De Hoge Raad deelt de opvatting dat het besluit tot het plaatsen van verkeersborden een exclusieve bestuurstaak is zodat het Openbaar Ministerie (hierna: OM) op dat punt niet-

13. Hier wordt volstaan met een bondige analyse van de zaak. Zie voor een meer uitvoerige analyse Rijnhout, Sikkema \& De Zanger 2014, Sikkema 2018 en M.J. Hornman, Y.R.S. Piekhaar en N. Rozemond, 'Stichtse Vecht en de vervolgbaarheid van overheden voor dodelijke ongelukken', NJB 2019, p. 722-728.

14. Rb. Utrecht 10 december 2012, ECLI:NL:RBUTR:2012:BY5595, NJ 2013/90 (Stichtse Vecht), r.o. 5.3.7.2.

15. Idem.

16. Kritisch hierover eveneens Rijnhout, Sikkema \& De Zanger 2014, p. 13.

17. Rijnhout, Sikkema \& De Zanger 2014, p. 13

18. CAG voor HR 20 februari 2018, ECLI:NL:HR:2018:236, NJ 2018/134 m.nt. N. Keijzer (Stichtse Vecht), punt 4.12. ontvankelijk had moeten worden verklaard. ${ }^{19}$ Anders dan zijn A-G meent de Hoge Raad echter dat het feit dat de zorgplicht voor het wegbeheer op de gemeente rust niet betekent dat het feitelijke onderhoud van die gemeentelijke wegen, waaronder ook moet worden verstaan het nalaten om dergelijk onderhoud te verrichten, naar zijn aard en gelet op het wettelijk systeem niet door anderen dan bestuursfunctionarissen in het kader van de uitvoering van de aan het openbaar lichaam opgedragen bestuurstaak kan worden verricht. ${ }^{20}$ Het gevolg daarvan is dat het OM enkel ontvankelijk is in de vervolging van dat deel van de tenlastelegging waarvan de rechtbank de gemeente juist heeft vrijgesproken omdat de schuld op dit punt onvoldoende kon worden vastgesteld. ${ }^{21}$

\section{Kritiek op het exclusieve bestuurstaak-criterium}

Van het exclusieve bestuurstaak-criterium is al eerder geconstateerd dat het onduidelijk en lastig hanteerbaar is. ${ }^{22} \mathrm{Na}$ de wisselende interpretaties die in de zaak Stichtse Vecht naar voren komen, ontkomt men eigenlijk niet aan de conclusie dat dit criterium gewoonweg onwerkbaar is. ${ }^{23}$ Het criterium is te gecompliceerd, multi-interpretabel en bij de rechtvaardigheid van de uitkomst kunnen bovendien vraagtekens worden geplaatst. Zeker in situaties waarin sprake is van een combinatie van omstandigheden die in onderlinge wisselwerking tot een bepaald gevolg hebben geleid, maar deels onder de immuniteit vallen, toont het criterium zijn beperkingen. De bovenstaande Stichtse Vecht-zaak maakt dat op een pijnlijke manier duidelijk. Het verwijt aan de gemeente bestond hier eigenlijk uit een optelsom van tekortkomingen waarvoor de gemeente gedeeltelijk immuniteit toekwam. De immuniteitsjurisprudentie legt daardoor ongewenste en forse beperkingen op aan de strafrechter en belet deze om het strafrechtelijk verwijt dat de decentrale overheid en/of haar feitelijk leidinggevers wordt gemaakt volledig en zorgvuldig te onderzoeken en te beoordelen. Een adequate beoordeling vergt een afweging van alle relevante gedragingen, ook van het doen en laten dat nu (deels) onder de immuniteit valt. ${ }^{24}$ Dat totaalbeeld wordt de rechter op dit moment onthouden. At best resteert daardoor een half-

19. HR 20 februari 2018, ECLI:NL:HR:2018:236, NJ 2018/134 m.nt. N. Keijzer (Stichtse Vecht), r.o. 3.7.2.

20. HR 20 februari 2018, ECLI:NL:HR:2018:236, NJ 2018/134 m.nt. N. Keijzer (Stichtse Vecht), r.o. 3.7.3. De ietwat wrange en al veelvuldig geconstateerde consequentie van deze redenering is dat als het ongeluk 50 meter verderop had plaatsgevonden, waar de gemeentelijke weg een rijksweg wordt, de centrale overheid voor dezelfde tekortkomingen volledige immuniteit zou genieten (Rijnhout, Sikkema \& De Zanger 2014, p. 14; Roef 2018a, par. 5)

21. Hornman, Piekhaar \& Rozemond 2019, p. 725.

22. De Hullu in punt 2 van diens noot onder HR 6 januari 1998 ECLI:NL:HR:1998:AA9342, NJ 1998/367 (Pikmeer II); Roef 2018b, p. 117; Sikkema 2018, p. 2.

23. Hornman, Piekhaar \& Rozemond 2019, p. 728.

24. Hornman, Piekhaar \& Rozemond 2019, p. 728. 
slachtig oordeel over de feitelijke toedracht en de strafrechtelijke verantwoordelijkheid daarvoor.

Daarnaast zijn het criterium van de exclusieve bestuurstaak en de bijzondere strafrechtelijke positie van overheidslichamen op zich al omstreden. Publiekrechtelijke en privaatrechtelijke rechtspersonen en hun functionarissen worden hierdoor immers op ongelijke voet behandeld, hetgeen nog eens extra precair is vanwege het feit dat de wetgever er tot op heden niet in is geslaagd om op overtuigende wijze uiteen te zetten waarom die ongelijke behandeling passend en geboden is. De omstandigheid dat een strafbare gedraging is verricht in het kader van de uitoefening van een publieke taak kan prima als relevante (en mogelijk mitigerende) factor worden meegewogen bij de inhoudelijke beoordeling van de strafzaak; een categorische uitsluiting is daarvoor niet nodig. Ook ondergraaft de immuniteit van de overheid de legitimiteit van haar optreden of van haar keuze om juist van optreden af te zien. ${ }^{25}$ Alles overziend verbaast het niet dat het - inmiddels verworpen - wetsvoorstel tot opheffing van die immuniteit in de literatuur met brede instemming werd ontvangen. ${ }^{26}$ Die verwerping maakt het voor de Hoge Raad echter lastig om aan de uitkomst van het politieke debat voorbij te gaan. De wetgever heeft zich duidelijk uitgesproken voor het voortzetten van de huidige immuniteitsjurisprudentie waardoor de speelruimte voor ons hoogste rechtscollege beperkt is. Kummeling en Vetzo stellen dat meer dan een nadere definiëring van het exclusieve bestuurstaak-criterium er onder deze omstandigheden niet in zit, tenzij de Straatsburgse jurisprudentie Nederland daartoe alsnog zou dwingen. ${ }^{27}$ Ook die jurisprudentie blinkt echter niet bepaald uit in helderheid.

\section{Kritiek op de gedeelde immuniteit}

Uit het accessoire karakter van feitelijk leidinggeven leidt de Hoge Raad in Pikmeer I af dat de feitelijk leidinggever deelt in de immuniteit van het openbaar lichaam waaraan deze is verbonden. De vervolgbaarheid van de rechtspersoon en de feitelijk leidinggever zijn immers 'zo nauw met elkaar verbonden dat de omstandigheid dat de rechtspersoon zelf niet vervolgd kan worden omdat deze een openbaar lichaam in de zin van Hoofdstuk 7 van de Grondwet is en optreedt ter vervul-

25. Rijnhout, Sikkema \& De Zanger 2014, p. 14; Sikkema 2006, p. 1999; Sikkema 2018, p. 2. Dat laatste lijkt de Hoge Raad ook te erkennen. In het Pikmeer II-arrest opent de Hoge Raad zijn aan het middel voorafgaande beschouwingen immers met de opmerking dat publiekrechtelijke rechtspersonen zich evenzeer als anderen aan de wet hebben te houden.

26. Zie o.a. De Valk 2009, p. 382-384 en 450-451; J. de Hullu, Materiee/ strafrecht. Over algemene leerstukken van strafrechtelijke aansprakelijkheid naar Nederlands recht, Deventer: Wolters Kluwer 2015, p. $129-130$ en 2018, p. 130-131; Rijnhout, Sikkema \& De Zanger 2014, p. 14; Sikkema 2006.

27. Kummeling \& Vetzo 2016, p. 62. In vergelijkbare zin Roef 2018b, p. 113 en 117. ling van een in de wet opgedragen bestuurstaak, meebrengt dat een strafvervolging evenmin kan worden ingesteld tegen ambtenaren en arbeidscontractanten in dienst van het openbaar lichaam indien dezen in die hoedanigheid ter uitvoering van die bestuurstaak opdracht hebben gegeven tot of feitelijk leiding hebben gegeven aan de verboden gedraging als bedoeld in art. 51 , tweede lid, onder $2^{\circ}$, Sr. $^{28}$ Deze doorwerking van de immuniteit van het openbaar lichaam naar de feitelijk leidinggever laat evenwel 'onverlet [...] dat de verdachte uit hoofde van eigen daderschap [kan worden] veroordeeld.' 29

Op deze koppeling is om meerdere redenen kritiek mogelijk. Allereerst doet het nogal willekeurig aan om de immuniteit van de vervolgde overheidsfunctionaris te laten afhangen van de concrete aansprakelijkheidsfiguur die het OM ten laste legt. De betrokkene deelt immers uitsluitend in de immuniteit van het openbare lichaam voor zover deze als feitelijk leidinggever wordt vervolgd. Wordt die vervolging ingestoken op basis van (functioneel) plegen of een van de reguliere deelnemingsvormen - zogenoemd 'eigen daderschap' -, dan kan de verdachte geen aanspraak maken op immuniteit en kan deze gewoon worden vervolgd, veroordeeld en bestraft. Dat getuigt niet echt van consistentie, noch van rechtvaardigheid. ${ }^{30}$ Bovendien doet dit afbreuk aan de overtuigingskracht van de immuniteitsjurisprudentie. Als er gegronde redenen zijn om gedragingen die zijn verricht in het kader van de uitoefening van een overheidstaak buiten het strafrecht te houden, dan zou die immuniteit onverkort moeten gelden, ongeacht de concrete aansprakelijkheidsfiguur waarlangs de vervolging wordt ingestoken. ${ }^{31}$ Daarnaast kan de toepassing van het exclusieve bestuurstaak-criterium zo uitpakken dat bepaalde gedragingen onder de immuniteit vallen en andere gedragingen niet. Het gevolg daarvan is weer dat bepaalde ambtenaren aansprakelijk kunnen worden gesteld en andere ambtenaren niet omdat zij delen in de immuniteit. Dat is niet alleen arbitrair, maar ook nog eens extra zuur wanneer de onder de immuniteit vallende gedragingen ernstiger zijn en een grotere causale bijdrage hebben geleverd aan het strafbare feit.

Voorts wordt betoogd dat deze gedeelde immuniteit onverenigbaar zou zijn met de positieve verplichtingen die voortvloeien uit het recht op leven zoals gegarandeerd door artikel 2 EVRM, ${ }^{32}$ in het bijzonder met het

28. HR 23 april 1996, ECLI:NL:HR:1996:ZD0429, NJ 1996/513 m.nt. A.C. 't Hart (Pikmeer I), r.o. 6.4; (herhaald in) HR 6 januari 1998, ECLI:NL:HR:1998:AA9342, NJ 1998/367 m.nt. J. de Hullu (Pikmeer II), r.o. 6.1.

29. HR 23 april 1996, ECLI:NL:HR:1996:ZD0429, NJ 1996/513 m.nt. A.C. 't Hart (Pikmeer I), r.o. 7.2.

30. Roef 2001, p. 383; C.H. Brants en R. de Lange, Strafvervolging van overheden, Deventer: Gouda Quint 1996, p. 60-66; 't Hart in diens noot onder HR 23 april 1996, ECLI:NL:HR:1996:ZD0429, NJ 1996/513 (Pikmeer I).

31. Om die reden pleitte A-G Van Dorst er in diens conclusie voor HR 23 april 1996, ECLI:NL:HR:1996:ZD0429, NJ 1996/513 (Pikmeer I) ook voor om de immuniteit eveneens te laten gelden voor de overige aansprakelijkheidsfiguren uit het strafrecht (zie Van Sliedregt 2013, p. 155).

32. Zie de eerder in voetnoot 6 aangehaalde literatuur. 
Öneryildiz-arrest. ${ }^{33}$ Dat arrest wordt veelal als richtinggevend beschouwd voor de invulling van de positieve verplichting die op staten rust in geval van niet-opzettelijke veroorzaking van de dood. De materiële kant van deze positieve verplichting houdt in dat staatsorganen en -functionarissen zich niet aan dergelijk mensenrechtenschendend gedrag schuldig mogen maken. De procedurele kant vergt van staten dat deze effectieve strafbepalingen hebben uitgevaardigd waarin zulk gedrag strafbaar is gesteld en dat er een opsporings- en vervolgingsapparaat moet zijn dat toeziet op het voorkomen en adequaat onderzoeken, vervolgen en waar nodig bestraffen van dergelijk gedrag. Deze procedurele verplichting gaat bij niet-opzettelijke levensberoving overigens niet zover als bij opzettelijke levensberoving. Alleen daar waar 'it is established that the negligence attributable to State officials or bodies on that account goes beyond an error of judgment or carelessness, in that the authorities in question, fully realising the likely consequences and disregarding the powers vested in them, failed to take measures that were necessary and sufficient to avert the risks inherent in a dangerous activity [...]', kan het uitblijven van gedegen onderzoek, een voortvarende vervolging en/of een passende bestraffing (inclusief de tenuitvoerlegging daarvan) resulteren in een schending van artikel 2 EVRM. ${ }^{34}$

\section{Persoonlijke aansprakelijkheid geen alternatief voor corporatieve aansprakelijkheid}

De immuniteit van de feitelijk leidinggever laat zich op het eerste gezicht moeilijk verenigen met bovenstaande procedurele verplichting. Nadere analyse van de positieve verplichtingen-rechtspraak laat evenwel zien dat die constatering moet worden genuanceerd. In deze en de twee navolgende paragrafen zal blijken waarom. Daarnaast is die rechtspraak zelf ook verre van zaligmakend en kunnen bij een aantal van de door het EHRM geformuleerde uitgangspunten kritische kanttekeningen worden geplaatst.

Vooropgesteld moet worden dat het EHRM verdragstaten een keuzemogelijkheid biedt. Het EHRM stelt - kortgezegd - dat 'de verantwoordelijken' voor mensenrechtenschendingen moeten kunnen worden bestraft, maar het laat in het midden wie die verantwoordelijken zijn. Het Hof spreekt over 'State officials or bodies', oftewel overheidsfunctionarissen of -lichamen. Het aanspreken van een van de twee volstaat. Op de vraag wie wanneer moet worden aangesproken geeft het EHRM

33. EHRM 30 november 2004, ECLI:NL:XX:2004:AS2641, NJ 2005/210 m.nt. E.A. Alkema (Öneryildiz/Turkije).

34. EHRM 30 november 2004, ECLI:NL:XX:2004:AS2641, NJ 2005/210 m.nt. E.A. Alkema (Öneryildiz/Turkije), r.o. 93 (curs. MJH). geen antwoord. Het enige dat uit de rechtspraak kan worden afgeleid is dat er iemand moet kunnen worden aangesproken, maar niet wie die iemand zou moeten zijn. Daaruit volgt dat het niet kunnen vervolgen van overheidsfunctionarissen niet problematisch hoeft te zijn, mits de publiekrechtelijke rechtspersonen waartoe zij behoren dan maar 'fully accountable' kunnen worden gehouden. ${ }^{35}$ Van rechtspraak die 'dwingt' tot de opheffing van de immuniteit van de feitelijk leidinggever is dus geen sprake. Op basis van deze rechtspraak zou hoogstens kunnen worden beweerd dat de immuniteit van een van beiden moet sneuvelen, maar niet dat dat per se de immuniteit van de feitelijk leidinggever moet zijn.

Dat laatste lijkt mij ook niet de meest wenselijke situatie. Behoefte aan verruiming van de vervolgingsmogelijkheden bestaat er vooral voor zover het de rechtspersoon betreft, zeker nu een aantal verdragstaten de strafbaarheid van rechtspersonen nog steeds afwijst en het merendeel van de staten die strafbaarheid wel erkennen terughoudend blijft waar het publiekrechtelijke rechtspersonen betreft. De door het Hof gesuggereerde inwisselbaarheid van ansprakelijkheid van beide rechtssubjecten is daardoor uiterst ongelukkig. De gekozen bewoordingen wekken de indruk dat rechtspersoon en functionaris gelijkwaardig zijn en dat de ansprakelijkheid van de een, een volwaardig alternatief vormt voor de ansprakelijkheid van de ander. Dat zou betekenen dat de overheid haar collectieve verantwoordelijkheid kan en mag afschuiven op individuele functionarissen. Dat is niet alleen onrechtvaardig, maar ook nog eens dogmatisch onzuiver. Collectieve schuld laat zich immers nauwelijks individualiseren. ${ }^{36}$ De Stichtse Vecht-zaak laat zien dat de oorzaak van het dodelijke ongeval was gelegen in een opeenstapeling van tekortkomingen begaan door verschillende medewerkers op verschillende momenten, zonder dat daarin één hoofdoorzaak of één hoofdverantwoordelijke kon worden aangewezen. Het ging om een opstelsom van fouten en stomme toevalligheden (ziekte van een ambtenaar, het begin van het broedseizoen waardoor de bomen niet konden worden geveld etc.) die als gevolg van een gebrekkige onderlinge afstemming binnen de gemeente erin kon resulteren dat kleine tekortkomingen fatale consequenties konden hebben. Het zijn dit soort aspecten als het organisatorisch tekort en de interne bedrijfscultuur waarin naar voren komt dat de aansprakelijkheid van de rechtspersoon een zelfstandig bestaansrecht heeft naast de aansprakelijkheid van natuurlijke personen. ${ }^{37}$ Verwijten op deze terreinen kunnen veelal niet worden teruggebracht tot een verwijt aan het adres van een of meer functionarissen binnen de gemeente. ${ }^{38}$ Het feit dat

35. EHRM 30 november 2004, ECLI:NL:XX:2004:AS2641, NJ 2005/210 m.nt. E.A. Alkema (Öneryildiz/Turkije), r.o. 117; Van Sliedregt 2013, p. 166.

36. Hornman, Piekhaar \& Rozemond 2019, p. 728; Rijnhout, Sikkema \& De Zanger 2014, p. 23; Roef 2018b, p. 122.

37. Hornman, Piekhaar \& Rozemond 2019, p. 728; Sikkema 2006, p. 2000.

38. In dezelfde zin Roef 2018a, par. 5; Rijnhout, Sikkema \& De Zanger 2014, p. 23; Roef 2018b, p. 122; Van Sliedregt 2013, p. 167. 
het openbare lichaam mogelijk strafwaardig heeft gehandeld hoeft derhalve nog niet te impliceren dat er binnen dat openbare lichaam ook concrete individuen kunnen worden aangewezen aan wie eveneens een strafrechtelijk relevant verwijt valt te maken.

De ervaring in België, waar vervolging van politieke mandatarissen wel mogelijk was maar vervolging van openbare lichamen met een verkozen orgaan volledig was uitgesloten, leert bovendien dat ervoor moet worden gewaakt dat al te gretig op zoek wordt gegaan naar potentiële feitelijk leidinggevers. Ingegeven door de wens om toch iemand te kunnen aanspreken, heeft de onmogelijkheid om de publiekrechtelijke rechtspersoon aan te spreken erin geresulteerd dat politieke ambtsdragers met vergaande en verwrongen schuldredeneringen persoonlijk verantwoordelijk werden gehouden. Dit leidde tot flinke onrust onder lokale politici en forse kritiek in de literatuur. De recente afschaffing van de immuniteit van publiekrechtelijke rechtspersonen in België lijkt dan ook vooral te zijn ingegeven door de wens om individuele overheidsfunctionarissen meer te ontzien, hetgeen nogmaals belicht dat persoonlijke strafrechtelijke aansprakelijkheid van overheidsfunctionarissen niet kan worden gezien als alternatief voor de aansprakelijkheid van het openbare lichaam zelf. ${ }^{39}$

De context die in België aanleiding vormde om de immuniteit op te heffen, is dus een geheel andere dan de discussie die in Nederland speelt. Niettemin kan de terughoudend in Nederland deels tegen de achtergrond van diezelfde problematiek worden verklaard. Ook in Nederland bestaat er soms de neiging om bij ernstige ongevallen, denk aan de Schipholbrand en het ongeluk met de monstertruck in Haaksbergen, direct te kijken naar de top van de organisatorische piramide en te focussen op de politiek verantwoordelijken: de minister, de wethouder of de burgemeester. Dat verklaart ook waarom de doorkruising van het systeem van politieke en bestuurlijke verantwoording wordt opgevoerd als bezwaar tegen de opheffing van de immuniteit. Het ter verantwoording roepen van politieke ambtsdragers dient te geschieden door democratisch gekozen volksvertegenwoordigers in de daarvoor bestemde gremia, niet in de rechtszaal. Persoonlijk acht ik dit risico op doorkruising niet zo groot omdat de vraag naar strafrechtelijke aansprakelijkheid een wezenlijk andere is dan die naar politieke verantwoordelijkheid. Het afleggen van bestuurlijke en strafrechtelijke verantwoording sluiten elkaar dan ook niet uit en rijden elkaar evenmin in de wielen en kunnen daarom prima naast elkaar bestaan en elkaar complementeren. ${ }^{40}$

Hoewel ik verwacht dat zich na een eventuele opheffing van de immuniteit de nodige artikel $12 \mathrm{~Sv}$-procedures tegen politiek ambtsdragers zullen aandienen, acht ik de kans op succes van dergelijke procedures uiterst klein. Politici hebben niet zo veel te vrezen, individuele ambtenaren des te meer. Strafrechtelijke aansprakelijkheid bestaat namelijk alleen voor eigen fouten en gedragin-

39. Roef 2018a, par. 5.

40. Zo ook Roef 2018b, p. 118-119. gen. Bovendien vergt feitelijk leidinggeven dat de betrokkene van de concrete aan het openbare lichaam verweten gedragingen, of van daarmee direct verbandhoudende gedragingen, op de hoogte was. ${ }^{41}$ Zeker bij grotere gemeenten zal de zoektocht naar feitelijk leidinggevers er vooral in resulteren dat personen behorende tot het lagere ambtelijke management zullen worden vervolgd. Zij zullen doorgaans over de vereiste kennis en mate van betrokkenheid beschikken om succesvol te kunnen worden aangesproken. Politici en hogere beleidsmakers zullen de dans ontspringen. Dit terwijl juist bij lagere managers en uitvoerende overheidsfunctionarissen de vraag rijst of zij wel over afdoende gewicht in de gemeentelijke organisatie(hiërarchie) beschikken om in geval van tegenstand (lees: beperkte financieringsmogelijkheden of prioritering) door te drukken dat de benodigde (preventieve) maatregelen tijdig worden genomen. ${ }^{42}$ Voorkomen moet worden dat het uitvoerende ambtenaren en lagere managers zijn die, indien de immuniteit zou worden opgeheven, opdraaien voor wat in de kern een uitvloeisel is van beleid dat hoger in de organisatiehiërarchie is vastgesteld, mede omdat dit tot een krampachtige opstelling onder ambtenaren en rigide handhaving uit angst voor aansprakelijkheid zou kunnen leiden. ${ }^{43}$ Dit gegeven is mijns inziens een veel groter punt van zorg en wordt in de discussie over de wenselijkheid van de strafrechtelijke overheidsaansprakelijkheid nog onvoldoende onderkend. Opheffing van de immuniteit is een goede zaak, maar niet zonder doordacht vervolgingsbeleid. ${ }^{44}$ Daarin moet niet alleen oog zijn voor het feit dat overheidshandelen doorgaans is ingegeven door het behartigen van het algemeen belang en veelal ziet op gewichtige, precaire en/of risicovolle maatschappelijke taken, maar ook voor de complexe organisatorische en maatschappelijke dimensie waarin dat overheidsoptreden gestalte krijgt. ${ }^{45}$ Dat overheidsaansprakelijkheid mogelijk wordt, hoeft derhalve geenszins te betekenen dat die aansprakelijkheid, en die van overheidsfunctionarissen in het bijzonder, eenvoudig wordt aangenomen. Een zekere terughoudendheid daarin lijkt mij zelfs wenselijk en goed te verdedigen. ${ }^{46}$

41. Dat is recentelijk nogmaals bevestigd in HR 26 april 2016, ECLI:NL:HR: 2016:733, NJ 2016/375 m.nt. H.D. Wolswijk (Overzichtsarrest feitelijk leidinggeven).

42. Vgl. Roef 2001, p. 383 en 577

43. Hoe groot de kans daarop is laat zich lastig beoordelen. Empirisch onderzoek naar bestuurdersaansprakelijkheid laat zien dat de angst om aansprakelijk te worden gesteld daar, in tegenstelling tot wat veelvuldig wordt beweerd (zie o.a. M.J. Kroeze, Bange bestuurders (oratie Rotterdam), Deventer: Kluwer 2005), nauwelijks een rol speelt (N.T. Pham, Directors' liability. A legal and empirical study (diss. Rotterdam), Deventer: Wolters Kluwer 2017).

44. Vgl. Punt 6 van de noot van 't Hart en punt 7 van de noot van De Hullu onder HR 23 april 1996, ECLI:NL:HR:1996:ZD0429, NJ 1996/513 (Pikmeer I) respectievelijk HR 6 januari 1998, ECLI:NL:HR:1998:AA9342, NJ 1998/367 (Pikmeer II) en Roef 2018b, p. 119.

45. Andere argumenten zijn dat de meeste (decentrale) openbare lichamen geen, of in ieder geval beperkte, zeggenschap hebben over de eigen inrichting, financiering en bevoegdheden. Veel taken zijn bij wet opgedragen en anders dan bij de meeste private rechtspersonen dus geen vrije keuze.

46. Vgl. Sikkema 2006, p. 2001. 
Waar strafrechtelijk gezien vooral het lagere ambtelijke management en uitvoerende ambtenaren in het vizier komen, ziet het politieke beoordelingskader er heel anders uit. Kennis of verwijtbaarheid spelen daar geen noemenswaardige, of in ieder geval geen doorslaggevende, rol. Zelfs zonder dat een wethouder persoonlijke blaam treft, kan deze besluiten om zijn of haar politieke verantwoordelijkheid te nemen of kan deze daartoe door de gemeenteraad worden gedwongen. Aldus valt niet in te zien hoe beide verantwoordingsmechanismen elkaar zouden frustreren.

Samenvattend: Het EHRM biedt verdragstaten een keuze bij hun vervolgingsbeleid. Vervolging van rechtspersoon of functionaris volstaat. Reeds om die reden kan niet worden volgehouden dat de immuniteit van de feitelijk leidinggever onverenigbaar is met de positieve verplichtingen-rechtspraak. Tegelijkertijd valt op die keuze het nodige af te dingen. Collectieve aansprakelijkheid is iets wezenlijk anders dan individuele aansprakelijkheid. Collectieve schuld laat zich dan ook zeer lastig individualiseren. Pogingen daartoe zullen vooral tot gevolg hebben dat het de ambtenaren uit de lagere regionen van de overheidsorganisatie zijn die zich voor de strafrechter zullen moeten verantwoorden.

\section{Straatsburgse drempel voor aansprakelijkheid}

Het doorslaggevende argument waarom de immuniteit niet onverenigbaar is met de positieve verplichtingenrechtspraak, is mijns inziens echter gelegen in het feit dat de lat die het EHRM hanteert om de positieve verplichting te activeren hoog ligt. Enkel daar waar het verwijt 'goes beyond an error of judgment or carelessness, in that the authorities in question, fully realising the likely consequences and disregarding the powers vested in them, failed to take measures that were necessary and sufficient to avert the risks inherent in a dangerous activity $[\ldots]$,', komt de positieve verplichting in beeld en bestaat er dus een verplichting om strafbaarheid te creëren en onderzoek en vervolging in te stellen en (indien gepast) tot bestraffing over te gaan. ${ }^{47}$ Duidelijk is dat onbewuste schuld niet volstaat. Veelal wordt uit deze passage afgeleid dat er sprake moet zijn van bewuste schuld wil er strijdigheid met het EVRM ontstaan. ${ }^{48}$ De vraag is of de lat zelfs niet nog hoger ligt. De bewoordingen van het EHRM zijn immers dusdanig geformuleerd dat niet in alle gevallen van bewuste schuld tot strafbaarheid hoeft te worden geconcludeerd. In de overweging wordt duidelijk gesproken over het uitstijgen boven een enkele inschattingsfout of een moment van onnadenkendheid of onachtzaamheid. Voor

47. EHRM 30 november 2004, ECLI:NL:XX:2004:AS2641, NJ 2005/210 m.nt. E.A. Alkema (Öneryildiz/Turkije), r.o. 93.

48. P.H.P.H.M.C. van Kempen, Repressie door mensenrechten (oratie Nijmegen), Nijmegen: Wolf Legal Publishers 2008, p. 29; Roef 2012, p. 188; Van Sliedregt 2013, p. 165 , bewuste schuld ligt de aansprakelijkheidslat evenwel lager. Eén enkele inschattingsfout, mits van voldoende ernst, kan daarvoor volstaan..$^{49}$ De ondergrens van culpa blijft in de jurisprudentie van het Hof daardoor duidelijk buiten de gevarenzone. In alle gevallen waarin het Hof tot de conclusie kwam dat de op de staat rustende positieve verplichting was geschonden, ging het om substantiële verwijten aan het adres van de overheid. ${ }^{50}$ Aan de norm 'fully realising the likely consequences and disregarding the powers vested in them' zal niet snel zijn voldaan. De oorzaak voor het uitblijven van passend overheidsoptreden zal doorgaans zijn gelegen in het feit dat die gevolgen niet adequaat zijn onderkend en dat de ernst van de situatie eerder is onderschat. Mogelijk omdat de primaire overtreder, de vergunninghouder waarop de overheid toezicht houdt, de ernst van diens overtredingen deels weet te maskeren en zodoende te onttrekken aan het zicht van de toezichthouder. ${ }^{51}$ Veelal worden de risico's pas na verwezenlijking in volle omvang duidelijk. Mits er voldoende onderzoek naar oorzaak wordt ingesteld, meen ik dat de keuze om in dergelijke gevallen van vervolging af te zien niet op Straatsburgse bezwaren zal stuiten. In geval van twijfel lijkt de balans uit te vallen in het voordeel van de staat die niet tot vervolging wenst over te gaan, zeker indien de desbetreffende overheidslichamen en hun functionarissen te goeder trouw zijn geweest.

Uit het voorgaande vloeit voort dat de gedeelde immuniteit van de feitelijk leidinggever enkel problematisch zou kunnen zijn wanneer de leidinggevende persoonlijk aan voornoemde schulddrempel voldoet. Echter, zelfs indien die drempel wordt gehaald en er dus een verplichting tot vervolging bestaat, dan volgt daaruit nog niet zonder meer dat de immuniteit van de feitelijk leidinggever direct onoverkomelijk is. De verplichting behelst alleen dat de betrokkene kan worden vervolgd en bestraft voor diens handelen en/of nalaten en dat de staat redelijke inspanningen moet tonen om te zorgen dat die vervolging en bestraffing ook voortvarend plaatsvinden. De rechtspraak van het EHRM verplicht er nergens toe dat die aansprakelijkheid ook via een bepaalde aansprakelijkheidsfiguur moet verlopen. De verplichting behelst enkel dat de tenlastelegging recht doet aan de (vermeende) ernst van de feiten zodat de onafhankelijke rechter de toedracht volledig en zorgvuldig kan onderzoeken en waar nodig passend kan bestraffen.

Omdat het EHRM alleen verplicht tot vervolging indien de aansprakelijkheidsdrempel - schuld die uitstijgt boven etc. - is gehaald en daarbij ook nog eens dicteert dat de vervolging recht moet doen aan de (vermeende)

49. HR 1 juni 2004, ECLI:NL:HR:2004:AO5822, NJ 2005/252 m.nt. G. Knigge (Black-out)

50. Zie o.a. EHRM 30 november 2004, ECLI:NL:XX:2004:AS2641, NJ 2005/210 m.nt. E.A. Alkema (Öneryildiz/Turkije); EHRM 15 december 2009, ECLI:NL:XX:2009:BL2007, AB 2010/292 m.nt. T. Barkhuysen en M.L. van Emmerik (Kalender e.a./Turkije); EHRM 20 maart 2008, ECLI:NL:XX:2008:BD6179, NJ 2009/229 m.nt. E.A. Alkema, AB 2008/206 m.nt. T. Barkhuysen en M.L. van Emmerik (Budeyava/ Rus(and).

51. De casussen S.E. Fireworks en Chemie-Pack bieden hiervan een helder voorbeeld. 
ernst van de feiten, resteert er slecht één optie: een vervolging wegens (een variant van) dood door schuld (art. $307 \mathrm{Sr}$ ). Dat is een commune en tot eenieder gerichte delictsomschrijving, zodat zich geen problemen met betrekking tot het normadressaatschap aandienen. ${ }^{52}$ Dat betekent dat de betrokkene bij voldoende mate van schuld zonder problemen uit hoofde van eigen daderschap zou moeten kunnen worden aangesproken. ${ }^{53}$ Daarin schuilt mijns inziens dan ook de crux. Het Hof verplicht alleen tot vervolging in omstandigheden die dusdanig ernstig zijn dat daarmee ook aan alle voorwaarden voor een veroordeling wegens dood door schuld zou moeten zijn voldaan en de door de Hoge Raad expliciet opengelaten alternatieve route van het eigen daderschap dus begaanbaar zou moeten zijn. Als er is geconstateerd dat er een verplichting tot vervolging bestaat, dan is daarmee ook gegeven dat er sprake is van persoonlijk verwijtbaar en aanmerkelijk onvoorzichtig handelen, oftewel van eigen daderschap wegens dood door schuld. Is een veroordeling wegens dood door schuld niet haalbaar, dan ligt in dat oordeel eveneens besloten dat de schuld van de betrokkene niet boven de aansprakelijkheidsdrempel uitstijgt. In dat geval kan de immuniteit die de betrokkene als feitelijk leidinggever geniet niet worden omzeild omdat er geen eigen daderschap is, maar bestaat er ook geen verplichting tot vervolging nu de daarvoor geldende aansprakelijkheidsdrempel niet is gehaald. Beide aspecten gaan wat mij betreft hand in hand.

Daaruit volgt mijns inziens ook dat het veel gehoorde standpunt dat de gedeelde immuniteit in strijd is met de positieve verplichtingen-rechtspraak niet juist is. In alle gevallen waarin die rechtspraak tot vervolging verplicht, is er een alternatief voorhanden in de vorm van dood door schuld wegens eigen daderschap waardoor de immuniteit van de feitelijk leidinggever kan worden omzeild. Dat neemt uiteraard niet weg dat het volledig opheffen van de immuniteit de beoordeling en vervolging van de tekortkomingen die zijn begaan door bestuursfunctionarissen in het kader van de uitoefening van hun publieke taak beduidend eenvoudiger zou maken, en om die reden ook zou zijn toe te juichen. Al was het maar omdat daardoor ook minder ingrijpende situaties die nog niet aan de Straatsburgse aansprakelijkheidsdrempel voldoen aan de strafrechter kunnen worden voorgelegd. Strikt noodzakelijk is die opheffing - anders dan doorgaans wordt betoogd - vanuit EVRMperspectief echter niet.

52. Dat laatste zou zich in theorie voor kunnen doen wanneer het openbare lichaam op basis van artikel 32 Arbowet wordt aangesproken, ware het niet dat die bepaling buiten de reikwijdte van de immuniteit valt ( $v g l$. Rb. Utrecht 9 juli 2003, ECLI:NL:RBUTR:2003:AH9535, AB 2003/332 m.nt. J.A.F. Peters (Verdronken brandweerman)).

53. Het gegeven dat iemand in de hoedanigheid van pleger in plaats van in de hoedanigheid van feitelijk leidinggever wordt aangesproken, maakt nog niet dat deze daardoor ineens als privépersoon wordt aangesproken. De verplichtingen die uit hoofde van zijn of haar functie op iemand rusten, rusten ook op hem of haar indien hij of zij als pleger wordt vervolgd. Anders - en mijns inziens onjuist - Hof Amsterdam 18 december 2018, ECLI:NL:GHAMS:2018:4662 en 4663 (vgl. HR 21 oktober 1986, ECLI:NL:HR:1986:AC9529, NJ 1987/362 (Bustehouders)).

\section{Beweerde noodzakelijkheid van strafrechtelijk onderzoek}

Het laatste argument dat wordt aangevoerd tegen de immuniteit is dat het EHRM bij vermeende schendingen van artikel 2 EVRM verplicht tot een strafrechtelijk onderzoek naar de exacte toedracht. Ook bij de stelligheid van die claim heb ik mijn twijfels. De onderzoeksplicht die het EHRM formuleert is tweeledig en valt uiteen in een onderzoek naar de toedracht van het ongeval en een onderzoek naar de aansprakelijkheid en bestraffing van eventuele verantwoordelijken. Veelal wordt aangenomen dat het eerste oriënterende onderzoek van strafvorderlijke aard moet zijn, omdat het onderzoek dat ziet op vervolging en bestraffing dat vanzelfsprekend ook is. De juistheid van die redenering kan worden betwijfeld. De reden die het EHRM in Öneryildiz aanvoert voor een strafrechtelijk onderzoek is namelijk van praktische aard. Nabestaanden hebben het recht om te weten wat er met hun geliefden is gebeurd en voor het achterhalen van die waarheid lijkt het EHRM het strafvorderlijk onderzoeksinstrumentarium met bijbehorende dwangmiddelen onmisbaar te achten. ${ }^{54}$ In veel andere verdragstaten is dat mogelijk ook het geval. In Nederland beschikt de Onderzoeksraad voor Veiligheid echter over vergaande bevoegdheden om de oorzaken en toedracht van rampen op te helderen. Daarbij geldt - ook voor verdachten, en anders dan in het strafrecht - een medewerkingsplicht. ${ }^{55}$ Daarmee gaat het praktische bezwaar van het EHRM tegen onderzoeken van niet-strafvorderlijke aard voor Nederland niet op. De Onderzoeksraad is als onafhankelijk en onpartijdig onderzoeksorgaan prima geëquipeerd om de waarheid te achterhalen. Dat betekent dat strafvorderlijk onderzoek enkel is aangewezen indien het eerste onderzoek aanknopingspunten oplevert dat de eerdergenoemde drempel voor strafrechtelijke aansprakelijkheid van individuen of instanties is gehaald en dat er dus vervolging moet worden ingesteld. Veel van het door de Onderzoeksraad verzamelde materiaal, waaronder onder dwang afgelegde verklaringen, mag immers niet in een strafvorderlijk onderzoek worden gebruikt. ${ }^{56}$ Het van meet af aan inzetten op strafrechtelijk onderzoek heeft als voordeel dat al het verkregen materiaal mag worden gebruikt en dat Nederland hoe dan ook aan de Straatsburgse kaders voldoet, ook indien gaandeweg de procedure zou blijken dat er onvoldoende aanknopingspunten zijn voor een strafrechtelijk verwijt. Die strafrechtelijke insteek bemoeilijkt evenwel de waarheidsvinding nu alle partijen in de strafvorderlijke procedure ook aanspraak

54. EHRM 30 november 2004, ECLI:NL:XX:2004:AS2641, NJ 2005/210 m.nt. E.A. Alkema (Öneryildiz/Turkije), par. 93. Zo interpreteer ik ook EHRM 20 maart 2008, ECLI:NL:XX:2008:BD6179, NJ 2009/229 m.nt. E.A. Alkema, AB 2008/206 m.nt. T. Barkhuysen en M.L. van Emmerik (Budayeva/Rusland) waar het Hof in par. 140 over 'indispensible' spreekt. Vgl. hierover ook Rijnhout, Sikkema \& De Zanger 2014, p. 18 en Roef 2012, p. 189.

55. Art. 40 Rijkswet Onderzoeksraad voor veiligheid (hierna: ROvv).

56. Art. 69 ROvv. 
mogen maken op de rechten die zij in het strafrecht hebben. Het gegeven dat Nederland met de strafvorderlijke optie hoe dan ook aan de norm van het EHRM voldoet, betekent mijns inziens echter niet dat een onderzoek door de Onderzoeksraad per definitie niet zou volstaan. ${ }^{57}$ Strijdigheid ontstaat mijns inziens pas indien uit het initiele onderzoek blijkt dat er sprake is van serieuze aanwijzingen voor strafrechtelijk laakbaar handelen waarbij de eerder genoemde aansprakelijkheidsdrempel wordt gehaald en er vervolgens geen strafvorderlijk vervolgonderzoek plaatsvindt. Wordt die drempel niet gehaald, en de lat voor die drempel ligt hoog, dan kan Nederland prima volstaan met een nietstrafrechtelijk onderzoek dat wordt uitgevoerd door de Onderzoeksraad voor Veiligheid.

\section{Conclusie}

Dat de Pikmeerjurisprudentie verre van ideaal is, staat buiten twijfel. In hoeverre deze immuniteitsjurisprudentie te verenigen valt met de positieve verplichtingenrechtspraak van het EHRM laat zich gezien de zeer casuistische rechtspraak lastig beoordelen. Dat er een spanningsveld bestaat, is echter evident. Als gevolg van de immuniteitsrechtspraak wordt de rechter immers (ernstig) beperkt in diens mogelijkheden om de feitelijke gebeurtenissen grondig en volledig te onderzoeken. Dit terwijl het EHRM een gedegen en onafhankelijk onderzoek verwacht dat, indien daartoe aanleiding bestaat, ook kan resulteren in een passende bestraffing van de verantwoordelijken. Tegelijkertijd wordt te gemakkelijk aangenomen dat de gedeelde immuniteit van de feitelijk leidinggever in strijd is met de Straatsburgse positieve verplichtingen-rechtspraak. Die rechtspraak verplicht ertoe om gedegen onderzoek in te stellen en de verantwoordelijken, indien daar voldoende anleiding toe bestaat, op een gepaste wijze te vervolgen en te bestraffen. Daaruit volgt dat het delict op basis waarvan vervolging wordt ingesteld recht moet doen aan de ernst van de feiten, hetgeen neerkomt op een vervolging wegens (een variant van) dood door schuld (art. $307 \mathrm{Sr}$ ). Vervolging wegens een lichter vergrijp zal niet volstaan en op zichzelf al in een schending van de op Nederland rustende positieve verplichting resulteren. Daarnaast geldt de verplichting alleen indien de mate van schuld boven de geformuleerde minimumdrempel uitstijgt. De verdachte moet persoonlijk ernstig verwijtbaar hebben gehandeld, en wel op zo'n manier dat dat handelen als dood door schuld kan worden gekwalificeerd. Met die constatering is gelijktijdig ook het eigen daderschap gegeven, zodat de immuniteit die de betrokkene als feitelijk leidinggever toekomt, kan worden omzeild. Komt men tot het oordeel dat de voornoemde minimumdrempel niet is gehaald, dan ontbreekt eigen daderschap en blijft de immuniteit overeind, maar dan ligt daarin eveneens besloten dat er geen positieve verplichting tot ver- volging bestond. Kortom: de gedeelde immuniteit van de feitelijk leidinggever vormt alleen een beletsel voor vervolging in die gevallen waarin het EHRM geen verplichting tot vervolging oplegt. Daarmee kan deze immuniteit om andere redenen nog steeds als onwenselijk worden beoordeeld, in strijd met de positieve verplichtingen-rechtspraak is zij echter niet.

Bovendien moet terughoudend worden omgesprongen met het aanspreken van individuen op collectief falen. Collectieve schuld laat zich niet individualiseren. Alle pogingen die daartoe worden ondernomen, resulteren er veelal in dat lagere functionarissen zich zullen moeten verantwoorden, terwijl de hogere echelons uit de organisatie die verantwoordelijk zijn voor de context waarbinnen deze lagere ambtenaren moeten functioneren buiten schot blijven. Daarom alleen al zou het wenselijk zijn om de immuniteit van openbare lichamen op te heffen en volledige vervolging van publiekrechtelijke rechtspersonen mogelijk te maken.

Tegelijkertijd moet ervoor worden gewaakt dat die aansprakelijkheid niet als bliksemafleider gaat fungeren. Dat de overheid in haar rol als toezichthouder een zekere verantwoordelijkheid heeft, neemt niet weg dat de hoofdverantwoordelijkheid nog steeds bij de primaire overtreder ligt. Onder toezicht gestelde partijen hebben nogal eens de neiging om de eigen verantwoordelijkheid af te schuiven en met de beschuldigende vinger wijzen naar de overheid die niet, te laat of onvoldoende heeft opgetreden. Dat bleek recentelijk nog in de zaak naar aanleiding van het incident met de monstertruck in Haaksbergen ${ }^{58}$ en eerder bij de cafébrand in Volendam en de vuurwerkramp in Enschede. Vaak als argument om de kwalijkheid van het eigen handelen te minimaliseren. Hoewel de overheid en haar functionarissen zeker een eigen verantwoordelijkheid hebben en daarop ook in rechte mogen worden aangesproken, moet het blikveld niet te snel verschuiven van de primaire overtreder naar de overheid. Juist in de discussie over de wenselijkheid van de strafrechtelijke aansprakelijkheid van de overheid en haar functionarissen dreigt de verantwoordelijkheid van de primaire veroorzaker te snel uit beeld te geraken. ${ }^{59}$ Dat de overheid en haar functionarissen mogelijk ook een verwijt valt te maken, doet niet af aan de eigen verantwoordelijkheid van de primaire overtreder. Beide aansprakelijkheden zijn geen communicerende vaten, zodat de verwijtbaarheid en verwerpelijkheid van het handelen van de primaire overtreder niet minder of anders wordt door het feit dat de overheid mogelijk ook iets te verwijten valt.

58. Zo richten Crince le Roy \& Wijling 2018 de pijlen niet alleen op de overheid, maar ook direct op de top van de gemeentelijke organisatie. Dat de burgemeester wellicht politiek verantwoordelijk is, betekent nog niet dat deze strafrechtelijk gezien ook aansprakelijk is. Laat staan dat de vergunninghouder die als professionele partij volledig bekend was met de risico's daar op enigerlei wijze in zijn eigen strafzaak van zou moeten profiteren.

59. Vgl. Barkhuysen \& Van Emmerik 2003, par. 5 